\title{
ASSESSMENT OF INVERSE CORRELATION OF P16 AND PRB EXPRESSION IN CARCINOMA EX PLEOMORPHIC ADENOMA
}

\author{
Bassel Tarakji ${ }^{1,2}$, Faris Alenzi ${ }^{3}$, Abdulaziz Abdullah Al-Khuraif $^{4}$
}

\begin{abstract}
1Department of Oral Maxillofacial Sciences, Al-Farabi College of Dentistry and Nursing, Riyadh, Saudi Arabia 2Department of Histology and Pathology, Faculty of Dentistry, University of Aleppo 3 College of Applied Medical Sciences, Salman bin Abdulaziz University, Al-Kharj, Saudi Arabia

4Dental Biomaterials Research Chair, Applied Medical Sciences College, King Saud University, Saudi Arabia
\end{abstract}

\begin{abstract}
Published data indicate that an inverse correlation has been identified in some tumours such as ovarian cancer and laryngeal squamous carcinoma.

This study aimed to characterize alteration in the immunohistochemical expression of p16 and pRb in carcinoma ex pleomorphic adenoma, and to assess the inverse correlation between $\mathrm{p} 16$ and $\mathrm{pRb}$ in carcinoma ex pleomorphic adenoma.

A selected series of 27 cases of carcinoma ex pleomorphic adenomas were examined at Alfarabi Dental School in 2012.

The results showed an inverse correlation between p16 (normal expression) and pRb (mutated) in 15 cases. Also 3 cases showed an inverse correlation between p16 (mutated) and $\mathrm{pRb}$ (normal expression). p16 and pRb (both proteins with normal expression) were identified in 3 cases. $\mathrm{p} 16$ and $\mathrm{pRb}$ (both proteins inactivated) were identified in 6 cases.

This study suggests the alteration of p16 and pRb expression has been detected in carcinoma ex pleomorphic adenomas. They mentioned that if the function of one gene such as $\mathrm{p} 16$ or $\mathrm{pRb}$ was abrogated the other gene would be overexpressed or unaffected in 18 out of 27 cases.
\end{abstract}

Key words: p16 and pRb expression, carcinoma ex pleomorphic adenoma.

\section{Introduction}

Several pathways need to be abrogated in the genesis of a malignant neoplasm. There is strong evidence that deregulation of one or more of the cell cycle checkpoints is among the most common abnormalities in human neoplasia. The protein p16 is a negative regulator of the cell cycle and is the product of the cyclin dependent kinase 2 (CDKN2) gene. Studies of the molecular genetics of oral cancer have shown that the CDKN2 gene was frequently inactivated by methylation or homozygous deletion [1].

The retinoblastoma protein $(\mathrm{pRb})$ is one of the key cell-cycle regulating proteins and its inactivation leads to neoplastic transformation and carcinogenesis [2]. Phosphorylation of $\mathrm{pRb}$ is mediated by complexes comprised of a D-type cyclin and cyclin-dependent protein kinases $(\mathrm{CDK} 4) /(\mathrm{CDK} 6)$. The activity of these kinas- es is in turn negatively regulated by cyclin kinase inhibitors including p16. The cascade composed of pRb, cyclin D1, CDK4/CDK6 and p16 plays a central role in cell cycle control. p16 controls cell proliferation through maintenance of a hypophosphorylated state of $\mathrm{pRb}$ [3]. It has been postulated that the $\mathrm{p} 16-\mathrm{pRb}$ pathway is regulated by a feedback loop involving $\mathrm{pRb}[4$, 5]. In such a case, deregulated expression of $\mathrm{pRb}$, by hyperphosphorylation, mutation, or association with viral oncoproteins, would permit high levels of p16.

Carcinoma ex pleomorphic adenoma (CPA) is considered to be a malignant transformation product of preexisting pleomorphic adenoma [6]. Carcinoma ex pleomorphic adenoma is the most common malignant mixed tumour and has been estimated to account for $10 \%$ of all salivary gland malignancy [7]. The goals of the present study were to investigate the alterations and aberrations in the expression of $\mathrm{p} 16$ and $\mathrm{pRb}$ in carcinoma 
ex pleomorphic adenoma, and also to evaluate the inverse correlation between $\mathrm{p} 16$ and $\mathrm{pRb}$ expression in 27 cases of carcinoma ex pleomorphic adenoma.

\section{Material and methods}

\section{Case selection}

Twenty seven cases of CPA from July 2011 to July 2012 were studied (Table I). Normal tissue of the salivary gland surrounding the tumour was used as a control. The criteria used to identify CPA by Nagao et al. [8] were considered. Malignant changes in the pleomorphic adenoma include three types (World Health Organization, 2005): CPA, carcinosarcoma, and metastasizing pleomorphic adenoma. The inclusion criteria for CPA including malignant transformation in pleomorphic adenoma include poorly defined and/or infiltrative tumour margins, the presence of foci of haemorrhage, and necrosis. Benign and malignant elements are considered as well. Exclusion criteria include the other well-recognized salivary carcinomas and those of uncertain type included in the current WHO histological classification of tumours [9]. All microscopic slides were reviewed by two pathologists to confirm the diagnosis. The ethical approval was included (Ref: 5/2012).

\section{Immunohistochemistry}

Serial $4-\mu \mathrm{m}$ sections were cut from 27 specimens. Streptavidin-biotin-peroxidase method was used. Endogenous peroxidase was blocked by $3 \%$ hydrogen peroxidase for 5 minutes, followed by TBS (Tris-buffered

Table I. Clinical data of 27 carcinoma ex-pleomorphic adenomas cases (CPA)

\begin{tabular}{|c|c|c|c|c|c|}
\hline CPA CASES & AGE & GENDER & GLAND & HISTOLOGICAL SUBTYPE & METASTASIS TO LYMPH NODES* \\
\hline 1 & 77 & $\mathrm{~F}$ & parotid & adenocarcinoma & yes \\
\hline 2 & 28 & $\mathrm{M}$ & parotid & adenocarcinoma & no \\
\hline 3 & 78 & $\mathrm{M}$ & submandibular & undifferentiated & yes \\
\hline 4 & 45 & $\mathrm{M}$ & parotid & undifferentiated & yes \\
\hline 5 & 76 & $\mathrm{~F}$ & parotid & undifferentiated & no \\
\hline 6 & 82 & $\mathrm{~F}$ & parotid & undifferentiated & no \\
\hline 7 & 71 & $\mathrm{M}$ & parotid & adenocarcinoma & no \\
\hline 8 & 67 & $\mathrm{M}$ & submandibular & undifferentiated & yes \\
\hline 9 & 63 & $\mathrm{M}$ & submandibular & undifferentiated & yes \\
\hline 10 & 55 & $\mathrm{M}$ & submandibular & undifferentiated & yes \\
\hline 11 & 73 & $\mathrm{M}$ & parotid & undifferentiated & yes \\
\hline 12 & 71 & $\mathrm{M}$ & parotid & undifferentiated & no \\
\hline 13 & 64 & $\mathrm{M}$ & parotid & undifferentiated & yes \\
\hline 14 & 60 & $\mathrm{~F}$ & parotid & undifferentiated & yes \\
\hline 15 & 49 & $\mathrm{~F}$ & submandibular & undifferentiated & no \\
\hline 16 & 39 & $\mathrm{~F}$ & parotid & undifferentiated & yes \\
\hline 17 & 56 & $\mathrm{M}$ & parotid & undifferentiated & no \\
\hline 18 & 45 & $\mathrm{~F}$ & parotid & undifferentiated & yes \\
\hline 19 & 57 & $\mathrm{M}$ & parotid & undifferentiated & yes \\
\hline 20 & 66 & $\mathrm{~F}$ & parotid & undifferentiated & no \\
\hline 21 & 86 & $\mathrm{~F}$ & submandibular & undifferentiated & yes \\
\hline 22 & 17 & $\mathrm{~F}$ & parotid & undifferentiated & no \\
\hline 23 & 78 & $\mathrm{M}$ & submandibular & undifferentiated & yes \\
\hline 24 & 26 & $\mathrm{M}$ & parotid & undifferentiated & no \\
\hline 25 & 31 & $\mathrm{~F}$ & parotid & undifferentiated & no \\
\hline 26 & 71 & $\mathrm{M}$ & parotid & undifferentiated & no \\
\hline 27 & 71 & $\mathrm{M}$ & parotid & undifferentiated & no \\
\hline 26 & 68 & $\mathrm{M}$ & submandibular & undifferentiated & no \\
\hline 27 & 54 & $\mathrm{~F}$ & parotid & undifferentiated & no \\
\hline
\end{tabular}

*Metastasis to lymph nodes at the time of tumour resection

$F$-female, $M-$ male 


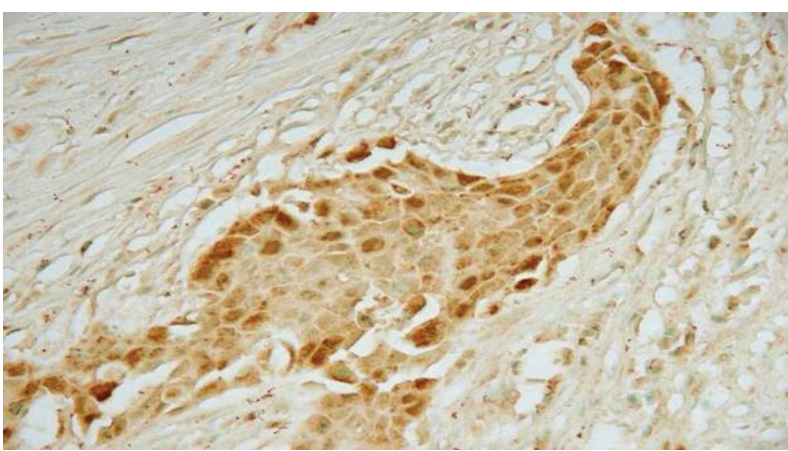

Fig. 1. Moderate nuclear staining of p16 in carcinoma ex pleomorphic adenoma. Original magnification $40 \times$

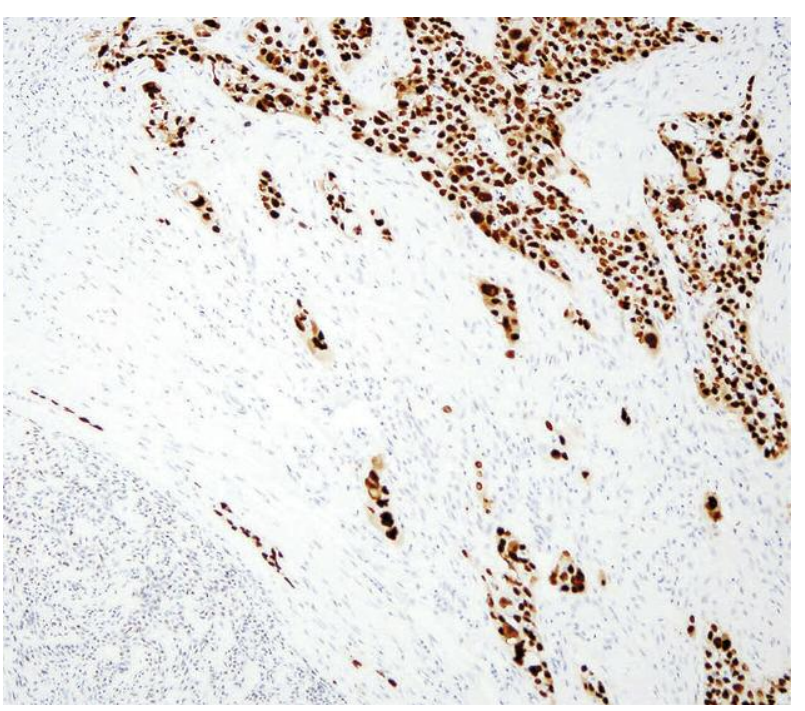

Fig. 2. Strong nuclear staining of $\mathrm{pRb}$ in carcinoma ex pleomorphic adenoma. Original magnification $40 \times$

saline) wash. Nonspecific immunoreactivity was blocked by incubation with normal goat serum for 20 minutes. A purified mouse anti-human monoclonal antibody p16 (Pharmingen, San Diego) was diluted to $5 \mu / \mathrm{ml}$ in $10 \mu / \mathrm{ml}$ tris buffer saline (TSA) for 1 hour at room temperature. A primary mouse anti-human retinoblastoma protein $\mathrm{RB}$ (Pharmingen, San Diego) was diluted to $5 \mu / \mathrm{ml}$ in $10 \mu / \mathrm{ml}$ tris buffer saline (TSA) containing $0.1 \%$ bovine serum albumin at room temperature. All sections were washed with TBS for 5 minutes. Sections were incubated with the biotinylated secondary antibody reagent for 30 minutes, followed by TBS wash for 5 minutes. Slides were incubated with streptavidin and horseradish peroxidase for 30 minutes, followed by TBS wash for 5 minutes, and incubated with a prepared chromogenic substrate solution (diaminobenzidine) for 15 minutes. Sections were counterstained with $0.25 \%$ methyl green in distilled water for 5 minutes. Sections were dehydrated and mounted in Depax. A positive control was included, squamous cell carcinoma. A negative control was included, substitution of the primary antibody with TBS. The assessment of $\mathrm{p} 16$ and $\mathrm{pRb}$ positive nuclei was as follows: negative (0) no expression of nuclear protein,
(1) weak staining $0-25 \%$ of the total cells shows positive staining in the nucleus, (2) moderate staining $>$ $25-75 \%$ of the total cells in the test area show positive nuclear staining, (3) strong staining $>75-100 \%$ cells show positive nuclear staining.

\section{Statistical analysis}

Cells of the carcinomatous component of the CPA were always scored. The statistical analysis included the use of descriptive statistics; frequencies proportion. Also, statistical analyses, including Wilcoxon's nonparametric tests (ordinal data), were performed on the data. All statistical tests were two-sided and p-values less than 0.05 were considered to be statistically significant.

\section{Results}

p16 expression of the nuclear staining was studied in an adjacent area of CPA. p16 nuclear staining of duct cells showed strong positive nuclear staining in $23(85 \%)$ cases out of $27,3(11.1 \%)$ with moderate staining, and $1(3.7 \%)$ with weak staining. p16 nuclear staining of the acinar cells showed negative staining in $1(3.7 \%)$ case out of $27,11(40.7 \%)$ had weak staining, and 15 $(55.5 \%)$ had moderate staining.

p16 expressed negative nuclear staining in 22 $(81.4 \%)$ cases out of 27 , and $5(18.5 \%)$ cases expressed moderate staining. There was a significant difference (Wilcoxon test, $\mathrm{p}$ value $<0.001$ ) between p16 expression in the nucleus in the duct cells of normal tissue surrounding the tumour and the tumour area. 23 out of 27 cases had strong positive staining detected in the duct cells (normal tissue) and no strong staining was noted in all cases of carcinoma arising in pleomorphic adenoma.

The results of nuclear staining of duct cells, acinar cells, and stroma indicated that $\mathrm{pRb}$ was not expressed in any of the 27 cases (control group).

$\mathrm{pRb}$ showed negative staining in 5 cases $(18.5 \%)$, 1 case had low staining (3.7\%), 2 moderate staining ( $7.4 \%)$, and 19 cases strong staining (70.4\%).

There was a significant difference (Wilcoxon test, $\mathrm{p}$ value $<0.001$ ) between $\mathrm{pRb}$ expression in the nucleus in the duct cells of normal tissue surrounding the tumour and the tumour area. pRb was not expressed in any of the 27 cases in the control group surrounding CPA. Nineteen cases out of 27 cases had strong positive staining detected in carcinoma arising in pleomorphic adenoma.

We reclassified the nuclear staining in the carcinoma cases to study the relation between p16 and pRb. Low and negative staining were considered negative but moderate and strong nuclear staining were considered positive. Table II shows the inverse correlation between p16 (normal expression) and pRb (mutated) in 15 cases. Also 3 cases showed an inverse correlation between p16 (mutated) and pRb (normal expression). p16 and 
$\mathrm{pRb}$ (both proteins with normal expression) were identified in 3 cases. $\mathrm{p} 16$ and $\mathrm{pRb}$ (both proteins inactivated) were identified in 6 cases.

\section{Discussion}

No study has been published on the inverse correlation between p16 and pRb in carcinoma arising in pleomorphic adenoma.

Nielsen et al. [10] reported that p16 showed positive staining in the duct and acinar cells of salivary glands. Hu et al. [11] investigated the p16 protein expression and promoter methylation of the $p 16$ gene in $\mathrm{CPA}$ and their roles in the malignant transformation of pleomorphic adenoma to CPA. They found no correlations between p16 protein expression and promoter methylation of the $p 16$ gene in either benign or malignant components. Schache et al. [12] demonstrated the successful application of quantitative methylation-specific real-time polymerase chain reaction (qMSP) analysis to a large series of historical carcinoma ex pleomorphic adenoma samples and reported on a panel of tumour suppressor genes (TSGs) with significant differences in their methylation profiles between benign and malignant variants of pleomorphic salivary adenoma. They concluded that qMSP analysis could be developed as a useful clinical tool to differentiate between CPA and its benign precursor. Augello et al. [13] reported that p16(INK4A) promoter hypermethylation was found in $100 \%(5 / 5)$ of carcinomas including 4 cases of cystic adenocarcinomas and 1 case of CPA. Patel et al. [14] examined cyclin D1 and p16 expression in 43 parotid tumours (29 pleomorphic salivary adenoma and 14 carcinoma ex pleomorphic). They reported that cyclin D1 and p16 were both significantly more likely to be expressed in the neoplastic than in the normal epithelial and stromal components of pleomorphic adenoma and carcinoma ex pleomorphic adenoma ( $\mathrm{P}<0.001$ and $\mathrm{P}<0.005$, respectively).

\section{The inverse correlation between p16 and $\mathrm{pRb}$ in carcinoma arising in pleomorphic adenoma}

Fang et al. [15] demonstrated pRb expression at higher levels in cell lines of human ovarian cancer lacking p16 than those with normal p16. They mentioned that if the function of one gene such as $\mathrm{p} 16$ or pRb was abrogated through deletion or mutation, the other gene would be overexpressed or unaffected. Therefore, they suggested that the growth inhibitory activity of this pathway would be maintained.

Yeager $e$ al. [16] reported an inverse correlation between p16 and pRb in human urothelial cells. Ten samples with normal expression of $\mathrm{pRb}$ showed low or no detectable p16 levels, while 7 samples with known pRb alterations showed abundant p16.
Table II. Shows p16 and pRb co-expression of the nuclear staining in carcinoma cases

\begin{tabular}{lcc}
\hline SLIDE ID NUMBER & \multicolumn{1}{c}{ P16 } & PRB \\
\hline 1 & negative staining & positive staining \\
\hline 2 & positive staining & positive staining \\
\hline 3 & positive staining & positive staining \\
\hline 4 & negative staining & positive staining \\
\hline 5 & positive staining & positive staining \\
\hline 6 & positive staining & positive staining \\
\hline 7 & negative staining & negative staining \\
\hline 8 & negative staining & negative staining \\
\hline 9 & positive staining & negative staining \\
\hline 10 & positive staining & negative staining \\
\hline 11 & positive staining & positive staining \\
\hline 12 & negative staining & positive staining \\
\hline 13 & positive staining & positive staining \\
\hline 14 & positive staining & positive staining \\
\hline 15 & negative staining & negative staining \\
\hline 16 & positive staining & positive staining \\
\hline 17 & negative staining & positive staining \\
\hline 18 & positive staining & positive staining \\
\hline 19 & positive staining & positive staining \\
\hline 20 & positive staining & positive staining \\
\hline 21 & positive staining & negative staining \\
\hline 23 & positive staining & positive staining \\
\hline 25 & negative staining & positive staining \\
\hline & positive staining & positive staining \\
\hline 25 & postaine staining & positive staining \\
\hline 25 &
\end{tabular}

Nagger et al. [17] showed that pRb and p16 expression exhibited a significant reciprocal correlation from primary oral and laryngeal squamous carcinoma specimens. Thirty-two tumours (91.4\%) showed an inverse relationship, 31 cases had negative p16 and positive $\mathrm{pRb}$ staining, and 1 showed negative $\mathrm{pRb}$ and positive p16 staining. Three $(8.6 \%)$ tumours were positive for both, and 1 tumour was negative for both proteins.

Sakaguchi et al. [18] also demonstrated an inverse relationship between $\mathrm{p} 16$ and $\mathrm{pRb}$ expression in nonsmall cell lung cancers. The expression of p16 and pRb protein was studied by immunochemistry in 61 cases. They found that 28 of 30 specimens did not stain for $\mathrm{p} 16$ but stained for $\mathrm{pRb}$ and 21 of $31 \mathrm{p} 16$ positive specimens did not stain for $\mathrm{pRb}$.

There are discrepancies in the results found in the literature because of different methodological problems. First, there may have been selection of patients and differences in treatment of different types of salivary gland 
tumours. Second, there are often differences in tissue processing from study to study, especially with regard to the type of antibody and the application of antigen retrieval. Also there are several steps in tissue processing that may influence staining patterns and intensity. These include type and duration of fixation, section thickness, antigen retrieval procedures, and type and concentrations of primary, second and third step antibodies. Third, and possibly most important, interpretation of staining and presentation of the results are not standardized, resulting in low intra-observer and interobserver reproducibility. Different criteria (e.g. $0=$ negative staining, $1=$ low, $2=$ moderate, $3=$ strong; or $0-3=$ negative and $4=$ positive; or $0-2=$ negative and $3-4=$ positive; or negative and positive staining) have been used in the literature to assess the expression of $\mathrm{p} 16$ and $\mathrm{pRb}$. Therefore, the use of one criterion such as negative or positive staining only for the assessment of staining will avoid any confusion in the interpretation of the results. There is therefore a clear need for a consensus on a protocol for scoring of immunohistochemical staining.

This study comprised 27 cases of CPA, which is much bigger than other published studies. The published literature on tumour markers in CPA is limited due to the fact that these tumours are rare. This study has shown an inverse correlation in 18 out of 27 cases of CPA, as mentioned above, so that if $\mathrm{p} 16$ or $\mathrm{pRb}$ is inactivated the other gene will show overexpression. The conclusion of this study is that the alteration of $\mathrm{p} 16$ and $\mathrm{pRb}$ expression has been detected in CPA cases. $\mathrm{P} 16$ and $\mathrm{pRb}$ might have a role in development of CPA.

\section{The authors declare no conflict of interest.}

\section{References}

1. Kashiwabara K, Oyama T, Sano T, et al. Correlation between methylation status of the $\mathrm{p} 16 / \mathrm{CDKN} 2$ gene and the expression of $\mathrm{p} 16$ and $\mathrm{Rb}$ proteins in primary non small cell lung cancers. Int J Cancer 1998; 79: 215-220.

2. Poznic M. Retinoblastoma protein: a central processing unit J Biosci 2009; 34: 305-312.

3. Giacinti C, Giordano A. RB and cell cycle progression. Oncogene 2006; 25: 5220-5227.

4. Koh J, Enders GH, Dynlacht BD, Harlow E. Tumour-derived p16 alleles encoding proteins defective in cell-cycle inhibition. Nature 1995; 375: 506-510.

5. Li Y, Nichols MA, Shay JW, Xiong Y. Transcriptional repression of the D-type cyclin-dependent kinase inhibitor p16 by the retinoblastoma susceptibility gene product $\mathrm{pRb}$. Cancer Res 1994; 54: 6078-6082.

6. Suzuki H, Fujioka Y. Deletion of the p16 gene and microsatellite instability in carcinoma arising in pleomorphic adenoma of the parotid gland. Diagn Mol Pathol 1998; 7: 224-231.

7. Numata T, Hiruma K, Tsukuda T, Asano T. Malignant mixed tumor. Gan To Kagaku Ryoho 2004; 31: 314-317.

8. Nagao K, Matsuzaki O, Saiga H, et al. Histopathologic studies on carcinoma in pleomorphic adenoma of the parotid gland. Cancer 1981; 48: 113-121.
9. Chen HH, Lee LY, Chin SC, et al. Carcinoma ex pleomorphic adenoma of soft palate with cavernous sinus invasion. World J Surg Oncol 2010; 8: 24.

10. Nielsen GP, Stemmer-Rachamimov AO, Shaw J, et al. Immunohistochemical survey of p16INK4A expression in normal human adult and infant tissues. Lab Invest 1999; 79: 1137-1143.

11. Hu YH, Zhang CY, Tian Z, et al. Aberrant protein expression and promoter methylation of p16 gene are correlated with malignant transformation of salivary pleomorphic adenoma. Arch Pathol Lab Med 2011; 135: 882-889.

12. Schache AG, Hall G, Woolgar JA, et al. Quantitative promoter methylation differentiates carcinoma ex pleomorphic adenoma from pleomorphic salivary adenoma. Br J Cancer 2010; 103: 1846-1851.

13. Augello C, Gregorio V, Bazan V, et al. TP53 and p16INK4A, but not H-KI-Ras, are involved in tumorigenesis and progression of pleomorphic adenomas. J Cell Physiol 2006; 207: 654-659.

14. Patel RS, Rose B, Bawdon H, et al. Cyclin D1 and p16 expression in pleomorphic adenoma and carcinoma ex pleomorphic adenoma of the parotid gland. Histopathology 2007; 51: 691-696.

15. Fang X, Jin X, Xu HJ, et al. Expression of p16 induces transcription downregulation of the RB gene. Oncogene 1998; 7 : $1-8$.

16. Yeager T, Stadler W, Belair C, et al. Increased p16 levels correlated with $\mathrm{pRb}$ alterations in human urothelial cells. Cancer Res 1995; 55: 493-497.

17. El-Naggar AK, Lai S, Clayman GL, et al. Expression of p16, Rb, and cyclin D1 gene products in oral and laryngeal squamous carcinoma: biological and clinical implications. Hum Pathol 1999; 30: 1013-1017.

18. Sakaguchi M, Fujii Y, Hirabayashi H, et al. Inversely correlated expression of p16 and $\mathrm{Rb}$ protein in non-small cell lung cancers: an immunohistochemical study. Int J Cancer 1996; 65: 442-445.

\section{Address for correspondence}

Bassel Tarakji

Department of Oral Maxillofacial Sciences

Al-Farabi Dental College, Riyadh, Saudi Arabia

fax: 00966-2324580

e-mail: denpol@yahoo.co.uk 